\title{
MENINGEAL CARCINOMATOSIS AS THE INITIAL MANIFESTATION OF A GALLBLADDER ADENOCARCINOMA ASSOCIATED WITH A KRUKENBERG TUMOR
}

\author{
Tizuko Miyagui, Luciana Luchemback, Graça Helena Maia do Canto Teixeira \\ and Kátia Martins Lopes de Azevedo
}

MIYAGUI T et al. - Meningeal carcinomatosis as the initial manifestation of a gallbladder adenocarcinoma associated with a Krukenberg tumor. Rev. Hosp. Clín. Fac. Med. S. Paulo 58 (3):169-172, 2003.

A case of malignant neoplasm is described in which the initial manifestations were mental dysfunction and meningeal irritation, mimicking chronic or subacute meningitis. Physical examination showed cranial nerve involvement and a pelvic tumor. There was progressive deterioration, and death occurred in 2 weeks. The autopsy revealed a gallbladder adenocarcinoma, meningeal carcinomatosis, and ovarian metastasis presenting as a Krukenberg tumor. The authors emphasize the importance of including meningeal carcinomatosis as a possibility in the differential diagnosis of non-characteristic clinical pictures, as well as the importance of the cerebrospinal fluid cytologic examination, repeated as needed, in order to confirm this diagnosis.

DESCRITORS: Ovarian neoplasms. Gallbladder cancer. Carcinomatosis. Metastasis. Meningitis.

Meningeal carcinomatosis (MC) is an infrequent manifestation of malignant neoplasia ${ }^{1,2}$. Pure MC implies in the involvement of the leptomeninges with no other metastasis elsewhere in the central nervous system $(\mathrm{CNS})^{2,3}$. Meningeal involvement may be focal, multifocal, or diffuse ${ }^{2}$. The incidence of MC appears to be increasing, perhaps due to longer survival of patients with malignant neoplasms. Nevertheless, MC is still considered infrequent, and its variable clinical manifestations make antemortem diagnosis difficult to achieve $e^{1,4,5}$. Headache, signs of meningeal irritation, abnormalities of the mental status, cranial nerve deficits, and seizures may indicate the leptomeningeal dissemination of a neoplasm primarily located outside the $\mathrm{CNS}^{3-5}$. Clinical objective signs related to the CNS can be more prominent than patient complaints, with findings corresponding to lesions involving the CNS at more than 1 anatomic site $e^{5}$. The presence of neoplastic cells in the cerebrospinal fluid (CSF) is diagnostic. Repeated CSF cytological examinations may be necessary ${ }^{4,5}$. We describe a case of gallbladder adenocarcinoma with 2 uncommon features: initial presentation as MC and ovarian dissemination as a Krukenberg tumor.

From the Departments of Pathology and Clinical Medicine, Infectious and Parasitic Disease Service, Antonio Pedro University Hospital, Faculty of Medicine, Fluminense Federal University, Rio de Janeiro/RJ, Brazil.

Received for publication on May 16, 2002.

\section{CASE REPORT}

A 43-year-old woman presented with agitation and mental confusion. She had experienced headaches and progressive changes in her mental status during the previous month. During this time, she was given symptomatics and psychological support. She had morbid obesity, with a body mass index (BMI) above 40 and arterial hypertension. Physical examination disclosed a palpable, painless, nonmotile pelvic mass. Obesity precluded further assessment. Neurological examination revealed nuchal rigidity and bilateral palsies of the 5th and 6th cranial nerves. During the physical examination, she had a tonic-clonic convulsion with sphincter incontinence, followed by convergent strabismus. A chest X-ray 
film was normal, and a cranial CT scan showed cerebral edema with mild ventricular dilatation. Cerebrospinal fluid (CSF) was mildly xanthochromic with 75 cells/mL (60\% neutrophils). Glucose and protein levels were $36 \mathrm{mg} / \mathrm{dL}$ and $123 \mathrm{mg} / \mathrm{dL}$, respectively. Viral or tuberculous meningitidis was suspected, and she was started on tuberculostatic drugs. A further CSF specimen with the same biochemical and cytologic characteristics gave a positive latex reaction to Cryptococcus neoformans. Amphotericin B was then substituted for tuberculostatic drugs, and mannitol was added. The patient's condition worsened, with torpor, bilateral amaurosis, and right facial nerve palsy. She progressed to coma and died 2 weeks later from cardiorespiratory arrest.

At autopsy both ovaries presented with solid tumors, the right one measuring $17 \times 11 \times 7 \mathrm{~cm}$ and weighing 650 $\mathrm{g}$ and the left one measuring $19 \times 17$ x $7 \mathrm{~cm}$ and weighing 1,400 g. The cut surface showed compact areas with a fascicular pattern intermingled with cystic areas containing a yellow gelatinous fluid. This was initially supposed to be a malignant ovarian primary neoplasm. There were para-aortic and peripancreatic metastatic lymph node enlargements. The gallbladder was filled with small calculi and had thickened walls with an irregular mucosal surface. The brain was edematous and weighed 1,400 g. There was a hernia of the right cerebellar tonsil and opacity of the leptomeninges, mainly on the basal areas.

Microscopic examination revealed a moderately differentiated adenocarcinoma of gallbladder (Fig. 1), with a scanty mucinous component. Normal ovarian architecture was entirely replaced by neoplastic cells disposed in alveolar and trabecular patterns; there were also mucinous and signet ring cells without any organization amidst a proliferated stroma. These findings completely supported the diagnosis of a Krukenberg tumor (Fig. 2). There was diffuse infiltration of the subarachnoid space (Fig. 3) that extended into the cortical parenchyma along the penetrating vessels. Other neoplastic changes were noted in lymph nodes, large intestine, and vertebral bone. A few emboli were found in small pulmonary arteries. The neoplastic cells showed characteristics of glandular cells, with positivity to PAS (Periodic Acid Schiff) and Alcean-blue stains.

\section{DISCUSSION}

Meningeal carcinomatosis, an uncommon complication of disseminated neoplasia, can nevertheless present as its initial manifestation ${ }^{1,6,7}$. It occurs more frequently with adenocarcinomas but can also be associated with squamocellular carcinomas and sarcomas $^{3,5}$. Meningeal carcinomatosis is rare in gallbladder neoplasia, and among the few cases described, there

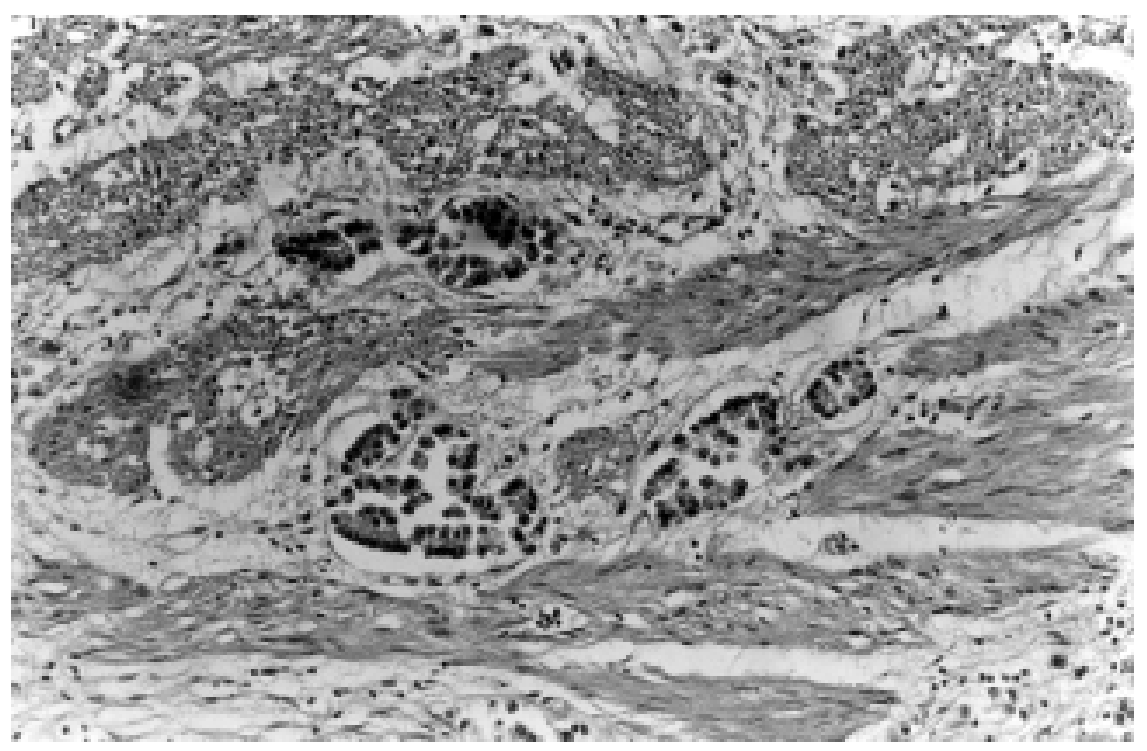

Figure 1 - Gallbladder: Neoplastic glandular structures infiltrating the muscular layer (Hematoxilyn and eosin x 100).

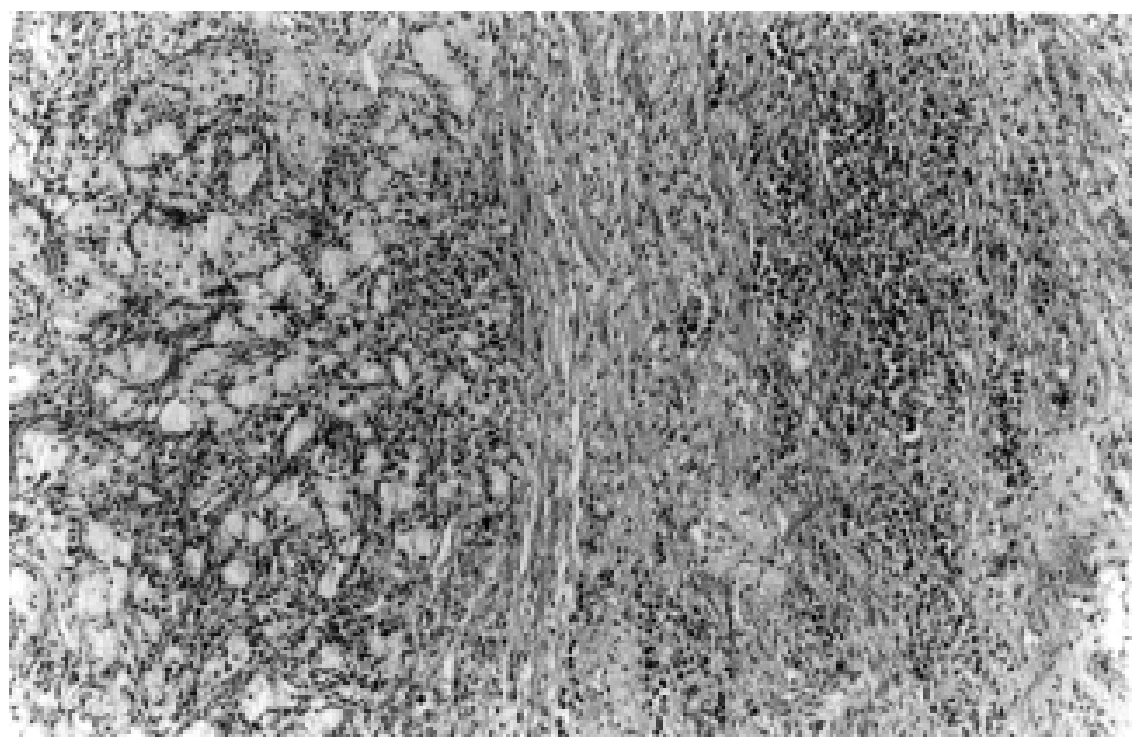

Figure 2 - Ovary: Compact neoplastic infiltration and stromal proliferation with areas of mucin secreting cells in acinar arrangement (Hematoxilyn and eosin x 100). 


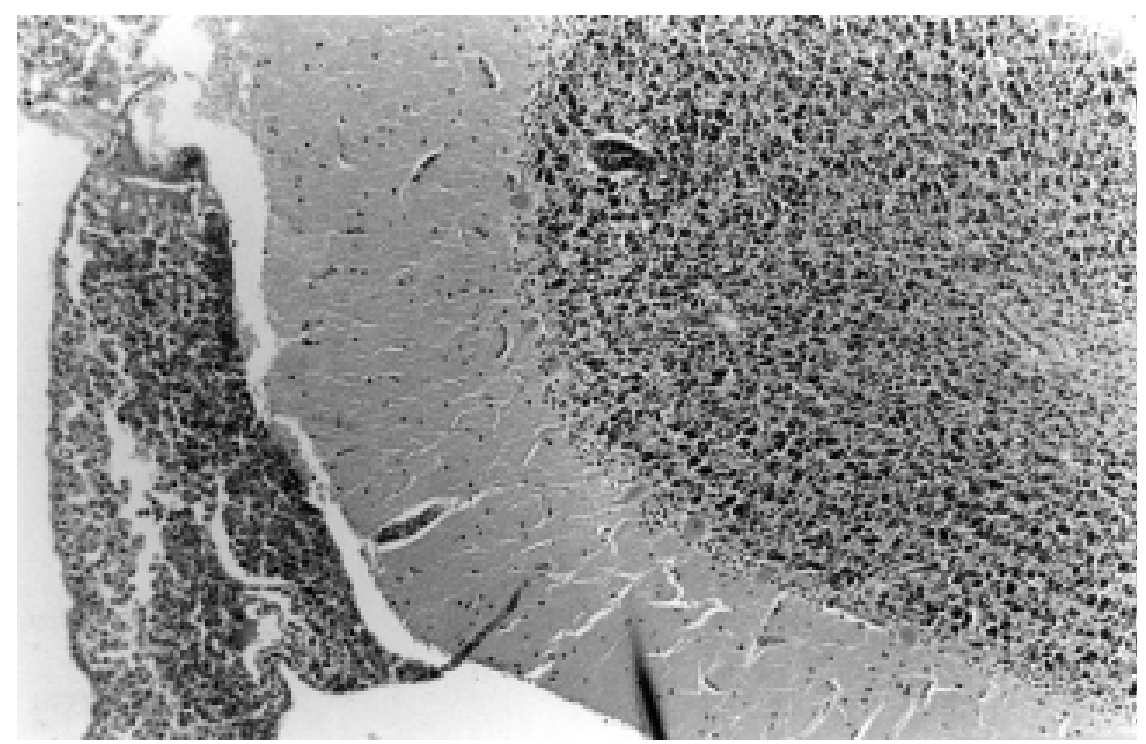

Figure 3 - Cerebellum: Subarachnoid space filled by neoplastic cells (Hematoxilyn and eosin $\mathrm{x}$ 100).

is only one in which MC was the initial clinical manifestation ${ }^{6}$. Meningeal carcinomatosis is more common in lung and breast carcinomas and in melanomas ${ }^{2,3,5,7}$. The paucity of neurologic manifestations can make diagnosis difficult, but the diversity of signals and symptoms as well as multifocal involvement, sometimes including cranial nerves or spinal roots, are both suggestive of $\mathrm{MC}^{5,7}$. Since CSF laboratory findings are similar, often the diagnostic problem is to distinguish MC from tuberculous or fungal meningitis ${ }^{5,8}$. Lumbar puncture yields clear or mildly turbid fluid with elevated pressure, low glucose levels, and high protein concentrations ${ }^{1,7}$. The presence of neoplastic cells in the CSF confirms the diagnosis. Repeated cytologic examinations may be necessary ${ }^{5,7,8}$. Positive diagnosis can be enhanced by tests for immunocytochemical reactions to carcinoembryonic (CEA) and anti-epithelial membrane (EMA) antigens and to cytokeratins, if they are available $e^{1,8,9}$. At gross examination, the brain may appear normal, or the leptomeninges can present milky opacity on the basal portions and along the vessels ${ }^{3,5}$.
Other findings are the presence of small nodules or focal granular changes in the meninges, mild hydrocephalus, and cerebral edema, as well as focal subarachnoid hemorrhage and laminar infarctions $\mathrm{s}^{3-5}$. Microscopically, there can be nonspecific changes such as meningothelial reaction, fibrosis, and inflammatory infiltration of the meninges. In the subarachnoid space, the neoplastic cells may be disposed in layers, clustered in small nodules, grouped in glandular structures, or diffusely spread, tending to concentrate in the basal areas near the brain stem or in non-plane areas such as the hippocampus sulci and cauda equina ${ }^{3,5}$. Neoplastic perivascular infiltration can extend to the cortical parenchyma $^{2,4,5}$.

The pathways by which neoplastic cells reach the meninges are still subject to controversy. Proposed routes are vascular (arterial or trough choroid and Batson venous plexuses), perivascular and perineural lymphatics, or spread by contiguity with adjacent bone or from CNS parenchymatous metastasis ${ }^{2,3,6}$. Each of these routes could alone explain MC, but this complication is more probably due to a combination of them. Cytokines secreted by tumor cells are also considered to play an important role in this kind of dissemination. There is evidence of synergic activity between TNF- $\alpha$ and cytokines in the development of $\mathrm{MC}^{10}$. In our clinical case, it was difficult to establish the route of dissemination. Since the ovaries were involved, it could be that neoplastic cells reached the leptomeninges through perineural lymphatics, due to the proximity of the ovaries to the lumbosacral nerves. Other possibilities are spread by contiguity with vertebral bone metastasis or dissemination by the neoplastic emboli that were detected in the pulmonary arteries (the hematogenous route).

Another infrequent complication present in this case of gallbladder adenocarcinoma was ovarian metastasis manifested as a Krukenberg tumor. This kind of metastasis is rare in gallbladder adenocarcinoma, being more common in adenocarcinoma of stomach or intestine, due to the higher frequency of mucinous or signet ring cells in these neoplasias. These types of neoplastic cells induce the infiltrating pattern of dissemination that is present in Krukenberg tumor and are not prone to develop nodular metastases ${ }^{11}$.

It is important to emphasize the exceptionality of a case of MC presenting as the initial manifestation of a gallbladder adenocarcinoma. The identification of a pelvic mass pointed to the possibility of a neoplasia. In spite of this, the clinical work-up was directed to the neurologic disease because of its severity. Some factors hindered the diagnosis of neoplastic disease, including the presence of lithiasis; the absence, excepting for the pelvic mass, of findings related to the malignant disease; and the false-positive CSF reaction to Cryptococcus neoformans. The diagnosis of neoplasia, of its primary localization, and of 
its dissemination to the leptomeninges was performed only at the postmortem examination.

Meningeal carcinomatosis is a neoplastic dissemination with poor prognosis, requiring intrathecal chemotherapy ${ }^{3,7}$. It is important that MC be included in the differential diagnosis of mycotic, tuberculous, and other forms of chronic meningitides ${ }^{5}$.
Cytologic examination for detection of neoplastic cells in the CSF must be performed, since these cells readily confirm the diagnosis, enabling specific treatment ${ }^{4,5,7,12}$.

\section{RESUMO}

MIYAGUI T e col. - Carcinomatose meníngea como manifestação inicial de um adenocarcinoma de vesícula biliar com tumor de Krukenberg. Rev. Hosp. Clín. Fac. Med. S. Paulo 58 (3):169-172, 2003.

Descreve-se um caso de neoplasia maligna cuja manifestação inicial foi distúrbio de comportamento e quadro de irritação meníngea, simulando uma meningite subaguda ou crônica. $\mathrm{Na}$ investigação clínica foram detectados o comprometimento de pares cranianos e a presença de massa tumoral pélvica. Houve piora progressiva, com evolução para o óbito em duas semanas. No exame post-mortem foram diagnosticados adenocarcinoma de vesícula biliar com componente mucinoso, carcinomatose meníngea e metástase ovariana sob a forma de um tumor de Krukenberg. Os autores mostram a importância da inclusão da carcinomatose meníngea no diagnóstico diferencial de quadros neurológicos incaracterísticos, e a necessidade de exames citológicos do liquor, às vezes repetidos, para a confirmação desta hipótese diagnóstica.

DESCRITORES: Neoplasia ovariana. Câncer de vesícula biliar. Carcinomatose. Metástase. Meningite.

\section{REFERENCES}

1. DEEB LS, YAMOUT BI, SHAMSEDDINE AI, et al. - Meningeal carcinomatosis as the presenting manifestation of gastric adenocarcinoma. Am J Gastroenterol 1997; 92(2):329-31.

2. KOKKORIS C P - Leptomeningeal carcinomatosis. How does cancer reach the pia-arachnoid? Cancer 1983; 51(1):154-60.

3. GONZALES-VITALE JC, GARCIA-BUNUEL R - Meningeal carcinomatosis. Cancer 1976; 37(6):2906-11.

4. WASSWERSTROM WR,GLASS JP, POSNER JB - Diagnosis and treatment of leptomeningeal metastases from solid tumors: experience with 90 patients. Cancer 1982; 49(4):759-72.

5. OLSON ME, CHERNIK N L, POSNER JB - Infiltration of the leptomeninges by systemic cancer- a clinical and pathologic study. Arch Neurol 1974; 30(2):122-37.

6. TANS RJJ, KOUDSTAAL J, KOEHLER PJ - Meningeal carcinomatosis as presenting symptom of a gallbladder carcinoma. Clin Neurol Neurosurg 1993; 95(3):253-6

7. HUFFMAN JL, YEATMAN TJ, SMITH JB - Leptomeningeal carcinomatosis: a sequela of cholangiocarcinoma. Am Surg 1997; 63(4):310-3.
8. THOMAS JE, FALLS E, VELASCO ME et al. - Diagnostic value of immunocytochemistry in leptomeningeal tumor dissemination- a report of two cases. Arch Pathol Lab Med $2.000 ; 124(5): 759-61$.

9. JORDA M, GANJEI-AZAR P, NADJI M - Cytologic characteristics of meningeal carcinomatosis. Arch Neurol 1998; 55(2):18194.

10. NAKAMURA S, NAGANO I, YOSHIOKA $M$, et al. Immunocytochemical detection of tumor necrosis factor- a in infiltrating tumor cells in the cerebrospinal fluid from five patients with leptomeningeal carcinomatosis. Acta Neurol Scand $1995 ;$ 91(2):137-40.

11. FOX H - Metastatic Tumours of the Ovary. In: HAYNES M, TAYLOR C, FOX H ed. - Obstetrical and Gynecological Pathology. $3^{\text {th }}$ ed. Edinburg, Livingstone, 1985. p. 714-23.

12. FIZAZI K, ASSELAIN B, VINCENT-SALOMON A, et al Meningeal carcinomatosis in patients with breast carcinoma. Clinical features, prognostic factors and results of a high-dose intrathecal methotrexate regimen. Cancer 1996; 77(7):131523. 